\title{
No association between the Ser9Gly polymorphism of the dopamine receptor D3 gene and schizophrenia: a meta-analysis of family-based association studies
}

\author{
Xiao-na Li ${ }^{1,3}$, Ji-long Zheng ${ }^{2}$, Xiao-han Wei ${ }^{1}$, Bao-jie Wang ${ }^{1}$ and Jun Yao ${ }^{1 *}$
}

\begin{abstract}
Background: Previous studies found that Ser9Gly (rs6280) might be involved in the occurrence of schizophrenia. However, no consist conclusion has yet been achieved. Compared to the case-control study, the family-based study took into account stratification bias. Thus, we conducted a meta-analysis of family-based studies to measure a pooled effect size of the association between Ser9Gly and the risk of schizophrenia.

Methods: The relevant family-based studies were screened using the electronic databases by the inclusion criteria. Odds ratios (ORs) and 95\% confidence intervals ( $\mathrm{Cls}$ ) were used to measure the correction between Ser9Gly polymorphism and schizophrenia susceptibility. Subgroup analysis was performed by stratification of ethnicity (i.e., East Asian, Caucasian, and other populations). Additionally, publication bias was evaluated by the funnel plot.

Results: After literature searching, a total of 13 family-based association studies were included, which contained 11 transmission disequilibrium test (TDT) studies with 1219 informative meiosis and 5 haplotype-based haplotype relative risk (HRR) studies. No statistical significance of the heterogeneity was detected in TDT and HRR studies. Thus, the pooled effect size was calculated under the fixed effect model. The results found that the association was significantly protective in East Asian in TDT studies (204 informative meiosis, OR $=0.744,95 \% \mathrm{Cl}=0.564-0.980$, Zvalue $=-2.104, p=0.035$ )

Conclusions: The meta-analysis based on the family study found a protective association of Ser9Gly in East Asian. In future, large sample molecular epidemiology studies are needed to validate our findings.
\end{abstract}

Keywords: Dopamine receptor D3, Schizophrenia, Meta-analysis, Family study

\section{Background}

Schizophrenia is a complex mental disorder with the incidence rate of about $1 \%$ in the word. Genetic and environmental factors are involved in its pathogenesis [1]. According to the report, heritability of schizophrenia is

\footnotetext{
* Correspondence: yaojun198717@163.com

${ }^{1}$ School of Forensic Medicine, China Medical University, No. 77, Puhe Road, Shenyang North New Area, Shenyang, Liaoning Province 110122, People's Republic of China

Full list of author information is available at the end of the article
}

as high as $80 \%$ [2]. So far, there has been no consist outcome regarding the etiology of this mental disorder [3, 4]. Recently, the studies have reported that the dysfunction of dopaminergic neurotransmitter may be involved in the development of schizophrenia [5-8]. Therefore, the genes participating in dopaminergic metabolism are the underlying susceptible genes in this disease.

Dopamine receptor D3 (DRD3) is localized to the limbic areas of the brain and are associated with cognitive, emotional, and endocrine functions [9-12]. It is encoded 
by $D R D 3$ gene. Ser9Gly variant (rs6280) is a functional polymorphic site in the first exon of DRD3 gene, which corresponds to a serine to glycine amino acid substitution at position 9 in the extracellular $\mathrm{N}$-terminal domain of DRD3 [13]. This variation can have a higher affinity for dopamine and amplify dopamine intracellular signaling [14]. Presently, Ser9Gly polymorphism has been reported to be related to neurological and psychiatric disorders [15-18]. For the association between Ser9Gly and schizophrenia, there are still conflicting results without a consistent conclusion [19-23]. These contradictory results may be due to small sample size, inclusion of various genetic backgrounds, and other potential confounding bias [24].

Meta-analyses can merge the various homogeneity studies and arrive at a comprehensive result $[25,26]$. Since 1998, the meta-analysis have been conducted to assess the association between Ser9Gly SNP and schizophrenia risk [27-33]. However, all of the pooled results were based on the case-control studies, but not the family-based studies. The family-based studies are more powerful to detect risk factors of schizophrenia, considering that the ability to exploit the cosegregation of variants with schizophrenia within families helps distinguish causal from noncausal factors [34]. Therefore, we carried out a meta-analysis of family-based association studies to better evaluate the relationship between DRD3 Ser9Gly SNP and the risk of schizophrenia.

\section{Methods \\ Literature search}

Three online electronic English databases (Medline, Embase, and Web of Science) and one online Chinese CNKI database were searched using the following key words: "DRD3", "dopamine receptor 3", "dopamine D3 receptor", "dopamine receptor D3", "schizophrenia", and "Ser9Gly". Additionally, the other possible studies were screened and retrieved by the reference lists of the included articles and the available reviews.

\section{Inclusion criteria}

The studies reporting Ser9Gly polymorhism were included after meeting the following criteria: (1) familybased design (original transmission disequilibrium test (TDT) [35] or haplotype-based haplotype relative risk (HRR) [36]; (2) original data, or available data to pool an effect size. Finally, we collected 13 articles and the flow

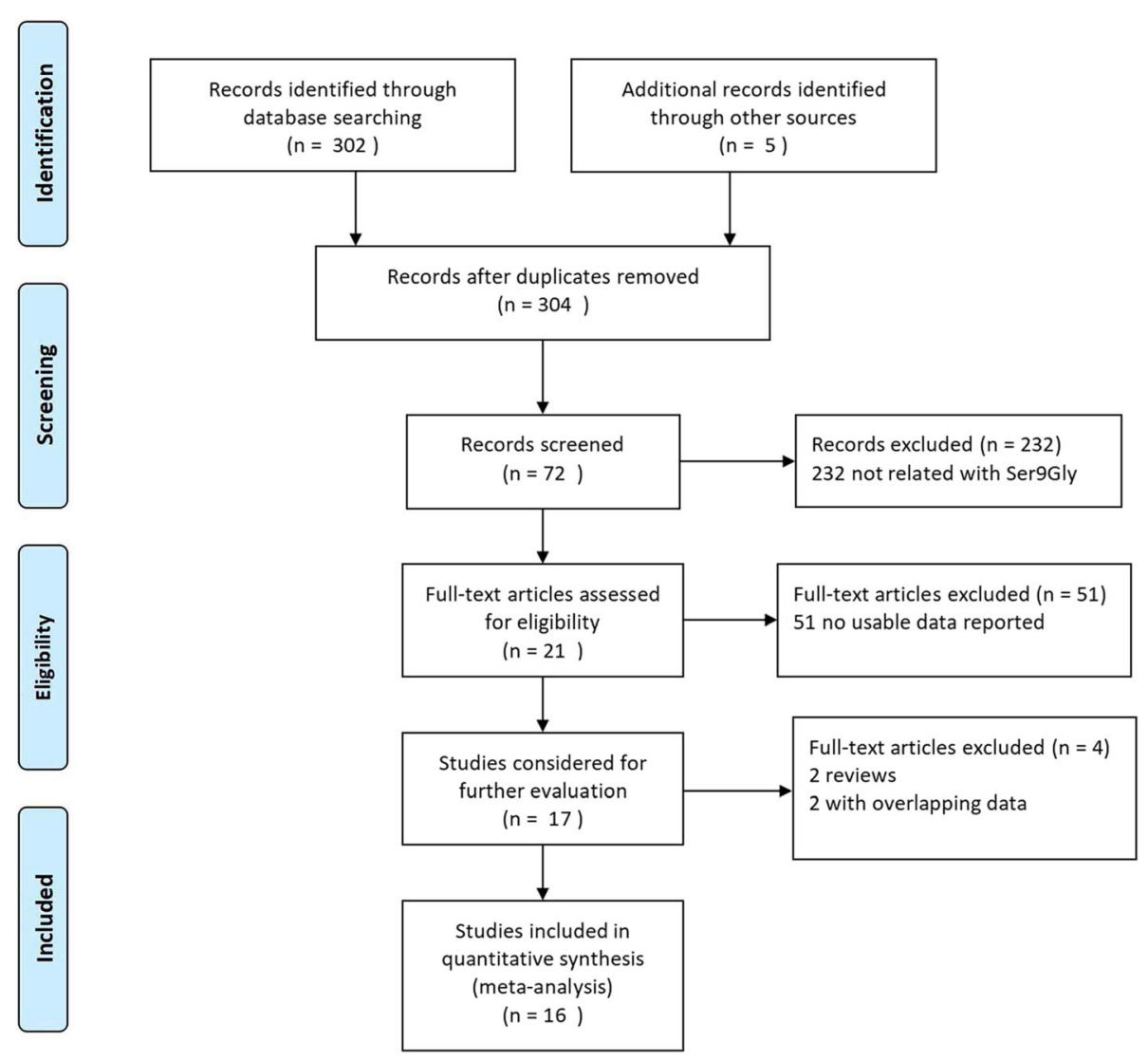

Fig. 1 The search flow diagram 
Table 1 Meta-analysis of TDT studies of the association between DRD3 Ser9Gly and schizophrenia

\begin{tabular}{|c|c|c|c|c|c|c|c|c|c|c|c|c|c|}
\hline \multirow[t]{2}{*}{ Author } & \multirow[t]{2}{*}{ Year } & \multirow[t]{2}{*}{ Location } & \multirow[t]{2}{*}{ Ethnicity } & \multirow{2}{*}{$\begin{array}{l}\text { Diagnostic } \\
\text { criteria }\end{array}$} & \multirow{2}{*}{$\begin{array}{l}\text { Number of } \\
\text { transmissions }\end{array}$} & \multicolumn{2}{|c|}{ Ser9 allele } & \multicolumn{2}{|c|}{ Expected distribution } & \multirow[t]{2}{*}{ OR } & \multirow[t]{2}{*}{$95 \% \mathrm{Cl}$} & \multirow{2}{*}{$\begin{array}{l}Z \text { - } \\
\text { value }\end{array}$} & \multirow{2}{*}{$\begin{array}{l}\boldsymbol{P} \text { - } \\
\text { value }\end{array}$} \\
\hline & & & & & & $\mathrm{T}$ & NT & T & NT & & & & \\
\hline Macciardi ${ }^{41}$ & 1994 & Italy & Caucasian & DSM-III-R & 108 & 57 & 51 & 54 & 54 & 1.118 & $0.766-1.630$ & 0.577 & 0.564 \\
\hline Rothschild ${ }^{42}$ & 1996 & USA & Caucasian & DSM-III-R & 71 & 43 & 28 & 35.5 & 35.5 & 1.536 & $0.959-2.459$ & 1.786 & 0.074 \\
\hline Malhotra ${ }^{43}$ & 1998 & USA & Caucasian & DSM-III-R & 149 & 74 & 75 & 74.5 & 74.5 & 0.987 & $0.716-1.360$ & -0.082 & 0.935 \\
\hline $\mathrm{Kalsi}^{44}$ & 1998 & British and Iceland & Caucasian & DSM-III-R & 78 & 33 & 45 & 39 & 39 & 0.733 & $0.469-1.146$ & -1.361 & 0.173 \\
\hline Williams ${ }^{26}$ & 1998 & Europe & Caucasian & DSM-III-R & 160 & 84 & 76 & 80 & 80 & 1.105 & $0.811-1.507$ & 0.633 & 0.527 \\
\hline Ambrósio $^{45}$ & 2004 & Portugal & Caucasian & DSM-IV & 74 & 35 & 39 & 37 & 37 & 0.897 & $0.569-1.416$ & -0.465 & 0.642 \\
\hline $\mathrm{Lu}^{46}$ & 2005 & China & East Asian & CCMD-III & 162 & 68 & 94 & 81 & 81 & 0.723 & $0.531-0.986$ & -2.047 & 0.041 \\
\hline Wang ${ }^{47}$ & 2006 & China & East Asian & CCMD-III & 42 & 19 & 23 & 21 & 21 & 0.826 & $0.451-1.515$ & -0.618 & 0.537 \\
\hline Talkowski ${ }^{48}$ & 2006 & USA & Caucasian & DSM-IV & 125 & 71 & 54 & 62.5 & 62.5 & 1.315 & $0.924-1.870$ & 1.523 & 0.128 \\
\hline Talkowski ${ }^{48}$ & 2006 & India & Indian & DSM-IV & 130 & 70 & 60 & 65 & 65 & 1.167 & $0.827-1.646$ & 0.877 & 0.380 \\
\hline Pawel $^{49}$ & 2010 & Poland & Caucasian & DSM-IV, ICD-10 & 120 & 57 & 63 & 60 & 60 & 0.905 & $0.632-1.294$ & -0.548 & 0.584 \\
\hline \multicolumn{3}{|c|}{ Subgroup of East Asian } & & & 204 & 87 & 117 & 102 & 102 & 0.744 & $0.564-0.980$ & -2.104 & 0.035 \\
\hline \multicolumn{3}{|c|}{ Subgroup of Caucasian } & & & 885 & 454 & 431 & 442.5 & 442.5 & 1.053 & $0.923-1.202$ & 0.771 & 0.441 \\
\hline \multicolumn{3}{|c|}{ Subgroup of DSM-III-R } & & & 566 & 291 & 275 & 283 & 283 & 1.058 & $0.897-1.248$ & 0.673 & 0.501 \\
\hline \multicolumn{3}{|c|}{ Subgroup of DSM-IV } & & & 449 & 233 & 216 & 224.5 & 224.5 & 1.079 & $0.897-1.298$ & 0.803 & 0.422 \\
\hline \multicolumn{3}{|c|}{ Subgroup of CCMD-III } & & & 204 & 87 & 117 & 102 & 102 & 0.744 & $0.564-0.980$ & -2.104 & 0.035 \\
\hline \multicolumn{3}{|l|}{ Total } & & & 1219 & 611 & 608 & 609.5 & 609.5 & 1.005 & $0.898-1.125$ & 0.086 & 0.932 \\
\hline
\end{tabular}

Note: $T$, transmitted (number of times the allele is transmitted from heterozygous parents to the proband); NT, not transmitted

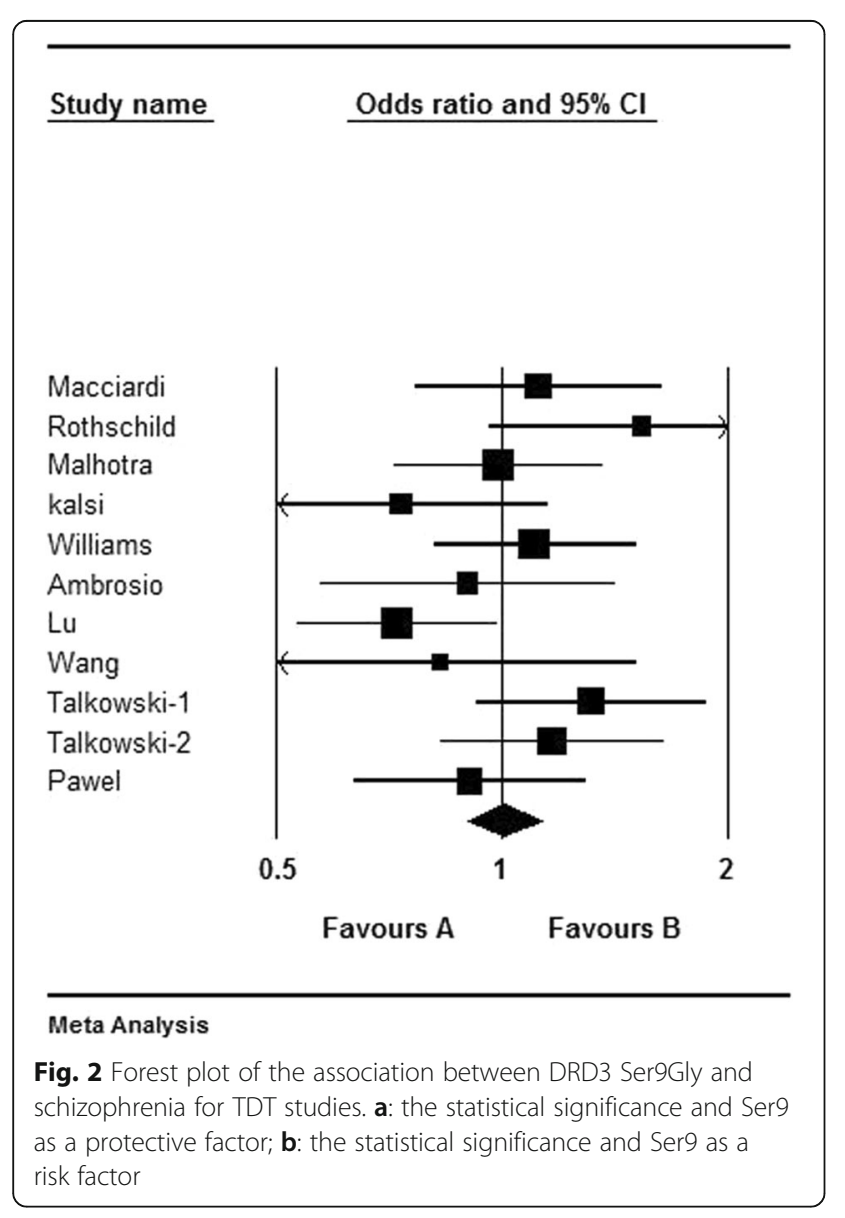

diagram of the literature search process was showed in Fig. 1.

\section{Data extraction}

The data extraction was independently conducted by two authors (XNL and BJW). Information collected included last name of first author, year of publication, country, ethnicity of study population, diagnostic criteria for schizophrenia, and numbers of transmissions.

\section{Meta-analytic methods}

The meta-analysis of the family-based association studies was divided into two parts: TDT and HRR. For the TDT study, every included study provided a 2-by-2 transmission disequilibrium table that classifies heterozygous parental alleles (informative meioses) based on the passing status (Ser9 allele passed to the schizophrenic offspring) and data type (the number of observed passing vs. the number of theoretic passing) [37]. For one informative meiosis, the expected transmitted number that the allele is transmitted from heterozygous parents to the proband is 0.5 and the expected untransmitted number that the allele is not transmitted from heterozygous parents to proband is also 0.5. For the HRR studies, every included study provided a 2-by-2 HRR table that classifies parental alleles by type of allele (Ser9 or Gly9) and passing status (passed to the offspring with schizophrenia or not) [37]. 


\section{Funnel Plot of Precision by Log odds ratio}

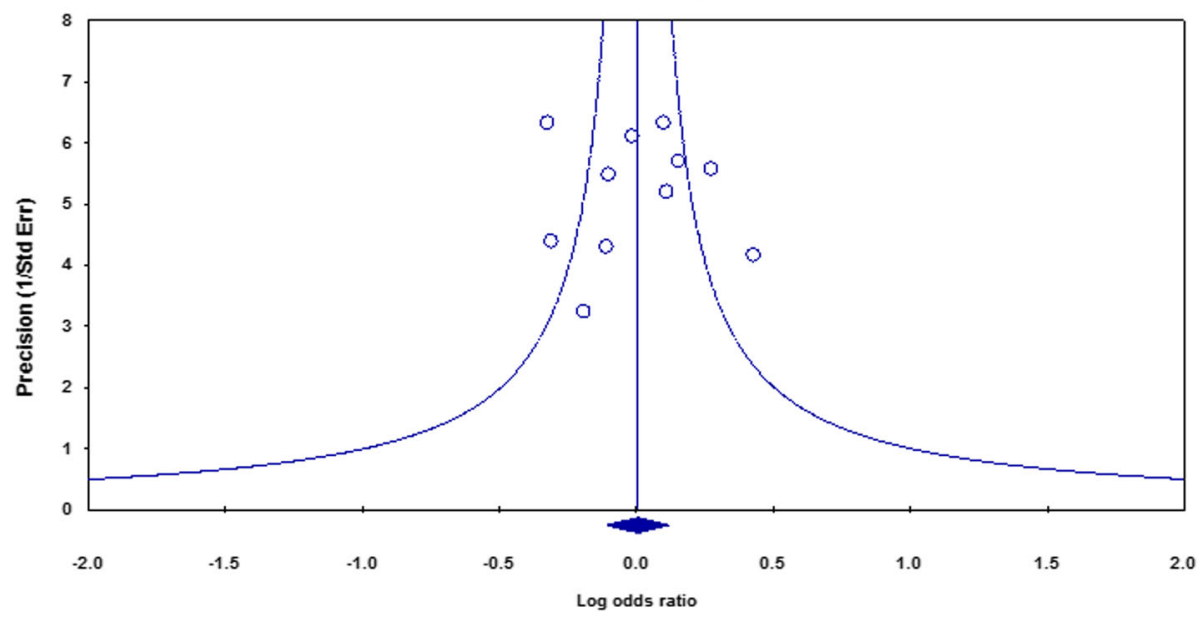

Fig. 3 Funnel plot of study precision by log odds ratio for TDT studies

The $Q$ test was used to measure the heterogeneity among the included studies and $P<0.05$ indicated the presence of heterogeneity $[38,39]$. Additionally, $\mathrm{I}^{2}$ was calculated to quantify the apparent inconsistency and its conventional interpretation for the existed heterogeneity was low $(<25 \%)$, moderate (approximately 50\%), and high $(>75 \%)$ [40]. When there was the existing of heterogeneity $\left(p<0.05\right.$ and/or $\left.\mathrm{I}^{2}>50 \%\right)$, a random effect model was selelcted; otherwise, a fixed effect model was selected using the Mantel and Haenszel method [38, 41].

For the pooled analysis, odds ratios (ORs) and 95\% confidence intervals (CIs) were calculated to quantify the association in the two-by-two Tables. $P>0.05$ indicated the absence of statistical significance, and $P<0.05$ indicated statistical significance. When $\mathrm{P}<0.05, \mathrm{OR}<1$ meant the variation as a protective factor, and $\mathrm{OR}>1$ meant the variation as a risk factor. Pooled calculations of ORs were obtained and compared with the controls (observed transmission vs. expected transmission for TDT study or transmitted vs. untransmitted for HRR study) using test statistic $\mathrm{z}$ and 95\% CIs. Moreover, subgroup analysis were conducted by ethnicity (i.e., East Asian, Caucasian, and other populations) and diagnostic criteria (i.e., DSM-III-R, DSM-IV, and CCMD-III). In addition, the funnel plot was generated to evaluate publication bias according to the previous study [37].

All the statistical calculations of the meta-analysis were performed by Comprehensive Meta Analysis V2 software (Biostat, Englewood, NJ, USA).

\section{Results}

A total of 13 articles were identified by database searches, which included 16 studies [27, 42-53]. Among them, 11 studies were for TDT and 5 studies were for HRR.

Table 1 showed the pooled ORs and 95\% CIs for the 11 original TDT studies with 1219 informative meiosis. There was no statistical significance for the heterogeneity $\left(\mathrm{I}^{2}=28.3 \%\right)$ and the fixed effect model was selected. The pooled results indicated that there were no association between Ser9Gly SNP and schizophrenia (1219

Table 2 Meta-analysis of HRR studies of the association between DRD3 Ser9Gly and schizophrenia

\begin{tabular}{|c|c|c|c|c|c|c|c|c|c|c|c|c|c|}
\hline \multirow[t]{2}{*}{ Author } & \multirow[t]{2}{*}{ Year } & \multirow[t]{2}{*}{ Location } & \multirow[t]{2}{*}{ Ethnicity } & \multirow{2}{*}{$\begin{array}{l}\text { Diagnostic } \\
\text { criteria }\end{array}$} & \multirow{2}{*}{$\begin{array}{l}\text { Sample } \\
\text { size }\end{array}$} & \multicolumn{2}{|c|}{ Transmitted } & \multicolumn{2}{|c|}{ Untransmitted } & \multirow[t]{2}{*}{ OR } & \multirow[t]{2}{*}{$95 \% \mathrm{Cl}$} & \multirow[t]{2}{*}{ Z-value } & \multirow[t]{2}{*}{$\boldsymbol{P}$-value } \\
\hline & & & & & & Ser9 & Gly9 & Ser9 & Gly9 & & & & \\
\hline Prasad $^{47}$ & 1999 & India & Indians & DSM-IV & 264 & 67 & 65 & 62 & 70 & 1.164 & $0.718-1.886$ & 0.615 & 0.538 \\
\hline Kremer ${ }^{48}$ & 2000 & Palestinian & Arabian & DSM-IV & 516 & 173 & 85 & 172 & 86 & 1.018 & $0.705-1.468$ & 0.094 & 0.925 \\
\hline Ambrosio ${ }^{42}$ & 2004 & Portugal & Caucasian & DSM-IV & 360 & 122 & 58 & 126 & 54 & 0.901 & $0.577-1.409$ & -0.455 & 0.649 \\
\hline $\mathrm{Lu}^{43}$ & 2005 & China & East Asian & CCMD-III & 404 & 94 & 108 & 120 & 82 & 0.595 & $0.401-0.882$ & -2.584 & 0.010 \\
\hline $\mathrm{Zai}^{49}$ & 2010 & Canada & Caucasian & DSM-IV & 160 & 46 & 34 & 50 & 30 & 0.812 & $0.431-1.530$ & -0.645 & 0.519 \\
\hline Total & & & & & 1704 & 502 & 350 & 530 & 322 & 0.869 & $0.713-1.059$ & -1.395 & 0.163 \\
\hline
\end{tabular}




\section{Study name Odds ratio and $95 \% \mathrm{Cl}$}

\section{Prasad \\ Kremer \\ Ambrosio \\ Lu \\ Zai}

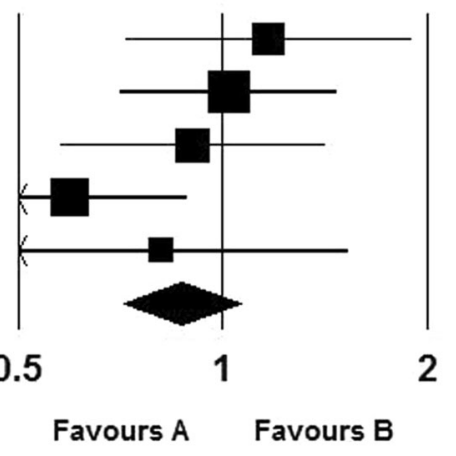

Meta Analysis

Fig. 4 Forest plot of the association between DRD3 Ser9Gly and schizophrenia for HRR studies. a: the statistical significance and Ser9 as a protective factor; b: the statistical significance and Ser9 as a risk factor

informative meiosis, $\mathrm{OR}=1.005,95 \% \mathrm{CI}=0.898-1.125$, $\mathrm{Z}$-value $=0.086, p=0.932$ ). The forest plot was showed in Fig. 2. Furthermore, we performed the subgroup analysis to further explore the association of Ser9Gly in Caucasian and East Asian populations, respectively. The results indicated the significantly preferential transmission of DRD3 Ser9 allele in East Asian (204 informative meiosis, $\mathrm{OR}=0.744,95 \% \mathrm{CI}=0.564-0.980, \mathrm{Z}$-value $=-$ 2.104, $p=0.035$ ), but not in Caucasian (885 informative meiosis, $\mathrm{OR}=1.053,95 \% \mathrm{CI}=0.923-1.202, \mathrm{Z}$-value $=$ $0.771, p=0.441$ ). Additionally, the subgroup analysis by diagnostic criteria showed that no association of Ser9Gly was found by DSM-III-R (566 informative meiosis, OR = $1.058,95 \% \mathrm{CI}=0.897-1.248, \mathrm{Z}$-value $=0.673, p=0.501$ ) and DSM-IV (449 informative meiosis, OR $=1.079,95 \%$ $\mathrm{CI}=0.897-1.298, \mathrm{Z}$-value $=0.803, p=0.422)$. However, there was an association of Ser9Gly by CCMD-III (204 informative meiosis, $\mathrm{OR}=0.744,95 \% \mathrm{CI}=0.564-0.980$, Z-value $=-2.104, p=0.035$ )

The studies distribution of the funnel plot was substantially symmetrical for the pooled effect size (Fig. 3). Thus, there was not enough evidence for publication bias for TDT studies.

Table 2 showed the pooled ORs and 95\% CIs for the 5 HRR studies with 1704 samples. There was no statistical significance for the heterogeneity $\left(\mathrm{I}^{2}=30.372 \%\right)$ and the fixed effect model was selected. The pooled results indicated that there were no association between Ser9Gly SNP and schizophrenia (1704 samples, OR $=0.869,95 \%$ $\mathrm{CI}=0.713-1.059$, Z-value $=-1.395, p=0.163)$. The forest plot was showed in Fig. 4. Furthermore, we performed the subgroup analysis to further explore the association of Ser9Gly in Caucasian population. The results indicated no significantly preferential transmission of DRD3 Ser9 allele in Caucasian (OR $=0.871,95 \% \mathrm{CI}=$ $0.604-1.254$, Z-value $=-0.744, p=0.457)$ (Table 3).

The studies distribution of the funnel plot was slightly asymmetrical for the pooled effect size (Fig. 5). A small but significant effect of publication bias for HRR studies was detected.

\section{Discussion}

We conducted a meta-analysis of family-based association studies (11 for TDT and 5 for HRR) to investigate the putative association of the Ser9Gly SNP in DRD3 with the risk of schizophrenia. Our overal results suggest that no association exists, except for the significantly preferential transmission of DRD3 Ser9 allele in East Asian in TDT studies.

Several previous meta-analyses have assessed the potential association of DRD3 Ser9Gly with the risk of schizophrenia in case-control studies [28, 29, 31-33, 54]. The latest meta-analysis, which included 73 studies comprising 10,634 patients with schizophrenia (cases) and 11,258 controls, suggested that the Ser9Gly SNP is not associated with schizophrenia [33]. Its finding was consistent with our study. Although the subgroup analysis of TDT meta-analysis observed the significant association between Ser9Gly and schizophrenia in East Asian population, it only included two studies with the limited

Table 3 Subgroup analysis of the association between DRD3 Ser9Gly and schizophrenia in HRR studies

\begin{tabular}{|c|c|c|c|c|c|c|c|c|c|c|c|c|}
\hline \multirow[t]{2}{*}{ Author } & \multirow[t]{2}{*}{ Year } & \multirow[t]{2}{*}{ Location } & \multirow[t]{2}{*}{ Ethnicity } & \multirow{2}{*}{$\begin{array}{l}\text { Diagnostic } \\
\text { criteria }\end{array}$} & \multicolumn{2}{|c|}{ Transmitted } & \multicolumn{2}{|c|}{ Untransmitted } & \multirow[t]{2}{*}{ OR } & \multirow[t]{2}{*}{$95 \% \mathrm{Cl}$} & \multirow{2}{*}{$\begin{array}{l}\text { Z- } \\
\text { value }\end{array}$} & \multirow{2}{*}{$\begin{array}{l}\boldsymbol{P}_{-} \\
\text {value }\end{array}$} \\
\hline & & & & & $\overline{\text { Ser9 }}$ & Gly9 & $\overline{\text { Ser9 }}$ & Gly9 & & & & \\
\hline Ambrosio $^{42}$ & 2004 & Portugal & Caucasian & DSM-IV & 122 & 58 & 126 & 54 & 0.901 & $0.577-1.409$ & -0.455 & 0.649 \\
\hline$Z a^{49}$ & 2010 & Canada & Caucasian & DSM-IV & 46 & 34 & 50 & 30 & 0.812 & $0.431-1.530$ & -0.645 & 0.519 \\
\hline Total & & & & & 168 & 92 & 176 & 84 & 0.871 & $0.604-1.254$ & -0.744 & 0.457 \\
\hline
\end{tabular}




\section{Funnel Plot of Precision by Log odds ratio}

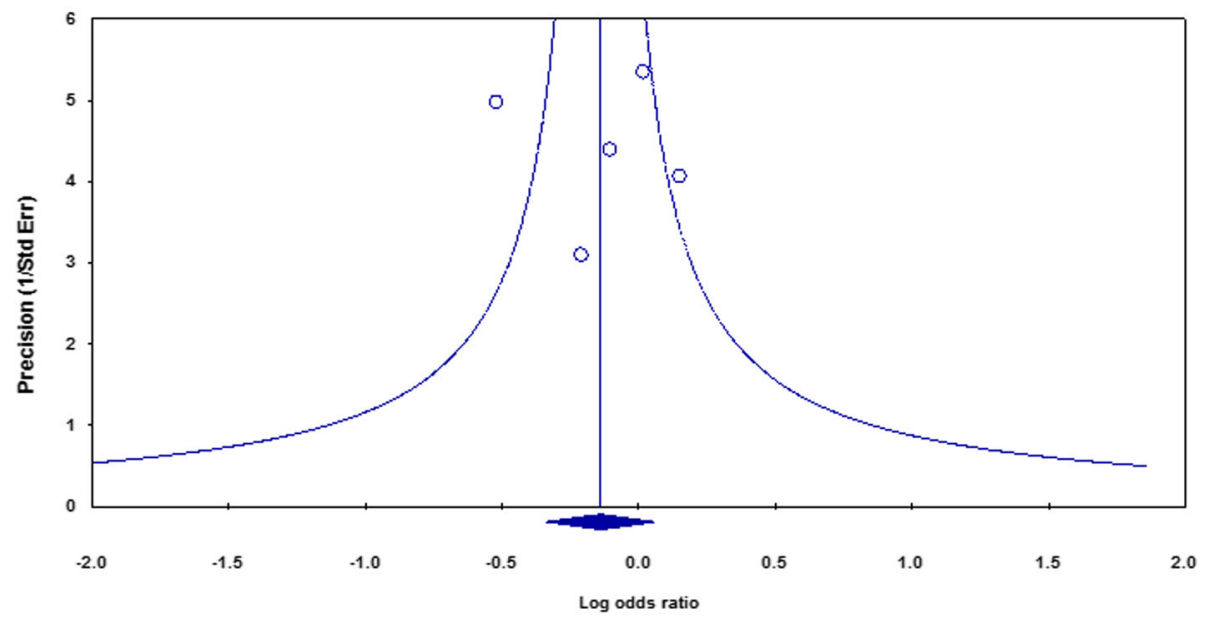

Fig. 5 Funnel plot of study precision by log odds ratio for HRR studies

sample size (204 meiosis) [47, 48]. The results of the significantly preferential transmission of DRD3 Ser9 allele in East Asian group showed that the serine allele appears to be protective against schizophrenia. Ser9Gly variant corresponds to a serine to glycine amino acid substitution at position 9 in the extracellular. The substituted glycine allele is thought to yield D3 autoreceptors having a higher affinity for dopamine and more robust intracellular signaling. Subsequently, the increasing DRD3dependant dopamine intracellular signaling may induce the occurrence of schizophrenia. Moreover, one study of HRR in East Asian also found the significant association, but its sample size was still small (404 samples) [47]. Thus, the positive results need to be interpreted cautiously and more work is required to validate the association in East Asian population. Additionally, it is reasonable that the genetic heterogeneity can lead to the differences in the subgroup analysis of Caucasian and East Asian. Actually, the genetic heterogeneity will complicate the etiology of schizophrenia because the allele distributions of $D R D 3$ Ser9Gly vary in different ethnicity population. Gly9 allele frequencies vary almost as much in the Japanese control populations $(22-34 \%)$ as they do in northern and western Caucasian control populations $(30-44 \%)[29,33]$. Therefore, in order to reduce the genetic heterogeneity, it is necessary to study the homogeneous populations.

Presently, numerous candidate genes are involved in the susceptibility of the complex disease, such as schizophrenia. Family-based association studies can provide an informative way to investigate the putative susceptible genes. Unlike population-based tests for association, the family-based tests for transmission disequilibrium are protected against population stratification and the results can avoid the effects of genetic background heterogeneity effectively [55]. Compared with the case-control study with the same sample size, the family-based study is less prone to confounding. Methodologically, it uses a more rigorous approach than the population-based study [56]. Thus, although our previous meta-analysis of casecontrol studies did not find the significant association of Ser9Gly locus with the risk of schizophrenia, it was still necessary to perform the meta-analysis of family based association.

There were two limitations in our current metaanalysis. Initially, we detected a slight but significant publication bias in the HRR studies. This bias might be due to only English- and Chinese-language studies included. Subordinately, we just evaluated the role of Ser9Gly SNP in the risk of schizophrenia. Nevertheless, only one variation just plays a minute role in the overall genetic susceptibility of the disease. Regrettably, the gene-gene interactions and epigenetics were not assessed without the sufficient information.

\section{Conclusions}

In conclusion, our meta-analysis of family-based association studies found no association between DRD3 Ser9Gly SNP and the risk of schizophrenia. The large sample homogeneous population studies will be necessary to further explore the role of DRD3 in the etiology of schizophrenia.

Abbreviations

SNP: Single nucleotide polymorphism; DRD3: Dopamine receptor D3; TDT: Transmission disequilibrium test; HRR: Haplotype-based haplotype relative risk; ORs: Odds ratios; Cls: Confidence interval 


\section{Acknowledgements}

Not applicable.

\section{Authors' contributions}

XNL, JLZ and XHW conceived and designed the experiments. XNL and BJW searched the literature, extracted and analyzed the data. JY wrote the paper. All authors have read and approved the final manuscript.

\section{Funding}

This study was supported by Foundation of Education Department of Liaoning Province (LQNK201743) for Dr. Xiao-na Li. The funders did not play any role in the study design, data collection, interpretation and preparation of the manuscript.

\section{Availability of data and materials}

All data generated or analysed during this study are included in this manuscript.

\section{Ethics approval and consent to participate}

Not applicable.

\section{Consent for publication}

Not applicable.

\section{Competing interests}

The authors declare that they have no competing interests.

\section{Author details}

${ }^{1}$ School of Forensic Medicine, China Medical University, No. 77, Puhe Road, Shenyang North New Area, Shenyang, Liaoning Province 110122, People's Republic of China. ${ }^{2}$ Department of Forensic Medicine, Criminal Investigation Police University of China, Shenyang, Liaoning 110035, People's Republic of China. ${ }^{3}$ School of Fundamental Sciences, China Medical University, No. 77, Puhe Road, Shenyang North New Area, Shenyang, Liaoning Province 110122, People's Republic of China.

Received: 17 June 2019 Accepted: 31 March 2020 Published online: 21 April 2020

\section{References}

1. Hoenders R, Bartels-Velthuis A, Vollbehr N, Bruggeman R, Knechtering R, de Jong J. Natural medicines in schizophrenia: a systematic review. J Altern Complement Med. 2014:20(5):A79.

2. Sullivan PF, Kendler KS, Neale MC. Schizophrenia as a complex trait: evidence from a meta-analysis of twin studies. Arch Gen Psychiatry. 2003; 60(12):1187-92.

3. Mueser KT, McGurk SR. Schizophrenia. Lancet. 2004;363(9426):2063-72.

4. Heron EA, Cormican P, Donohoe G, O'Neill FA, Kendler KS, Riley BP, Wellcome Trust case control C, Gill M, Corvin AP, Morris DW. No evidence that runs of homozygosity are associated with schizophrenia in an Irish genome-wide association dataset. Schizophr Res. 2014;154(1-3):79-82.

5. Abi-Dargham A, Moore H. Prefrontal DA transmission at D1 receptors and the pathology of schizophrenia. Neuroscientist. 2003;9(5):404-16.

6. Fan H, Zhang F, Xu Y, Huang X, Sun G, Song Y, Long H, Liu P. An association study of DRD2 gene polymorphisms with schizophrenia in a Chinese Han population. Neurosci Lett. 2010;477(2):53-6.

7. Howes OD, Kapur S. The dopamine hypothesis of schizophrenia: version III-the final common pathway. Schizophr Bull. 2009:35(3):549-62.

8. Davis J, Moylan S, Harvey BH, Maes M, Berk M. Neuroprogression in schizophrenia: pathways underpinning clinical staging and therapeutic corollaries. Australian New Zealand J Psychiatry. 2014

9. Fageera W, Sengupta SM, Labbe A, Grizenko N, Joober R. DRD3 gene and ADHD: a Pharmaco-Behavioural genetic study. NeuroMolecular Med. 2018; 20(4):515-24.

10. Yamamoto K, Fontaine $R$, Pasqualini $C$, Vernier $P$. Classification of dopamine receptor genes in vertebrates: nine subtypes in Osteichthyes. Brain Behav Evol. 2015;86(3-4):164-75.

11. Sokoloff P, Giros B, Martres MP, Andrieux M, Besancon R, Pilon C, Bouthenet ML, Souil E, Schwartz JC. Localization and function of the D3 dopamine receptor. Arzneimittel-Forschung. 1992;42(2A):224-30.
12. Yang B, Niu W, Chen S, Xu F, Li X, Wu X, Cao Y, Zhang R, Yang F, Wang L, et al. Association study of dopamine receptor genes polymorphisms with the risk of schizophrenia in the Han Chinese population. Psychiatry Res. 2016:245:361-4.

13. Utsunomiya K, Shinkai T, Sakata S, Yamada K, Chen HI, De Luca V, Hwang R, Ohmori O, Nakamura J. Genetic association between the dopamine D3 receptor gene polymorphism (Ser9Gly) and tardive dyskinesia in patients with schizophrenia: a reevaluation in east Asian populations. Neurosci Lett. 2012;507(1):52-6.

14. Savitz J, Hodgkinson CA, Martin-Soelch C, Shen PH, Szczepanik J, Nugent A, Herscovitch P, Grace AA, Goldman D, Drevets WC. The functional DRD3 Ser9Gly polymorphism (rs6280) is pleiotropic, affecting reward as well as movement. PLoS One. 2013;8(1):e54108.

15. Jhun E, He Y, Yao Y, Molokie RE, Wilkie DJ, Wang ZJ. Dopamine D3 receptor Ser9Gly and catechol-o-methyltransferase Val158Met polymorphisms and acute pain in sickle cell disease. Anesth Analg. 2014;119(5):1201-7.

16. Chang TT, Chen SL, Chang YH, Chen PS, Chu CH, Chen SH, Huang SY, Tzeng NS, Wang LJ, Wang TY, et al. The DRD3 Ser9Gly polymorphism predicted metabolic change in drug-naive patients with bipolar II disorder. Medicine. 2016;95(24):e3488.

17. Xu S, Liu J, Yang X, Qian Y, Xiao Q. Association of the DRD2 CAn-STR and DRD3 Ser9Gly polymorphisms with Parkinson's disease and response to dopamine agonists. J Neurol Sci. 2017;372:433-8.

18. Zai CC, Manchia M, Sonderby IE, Yilmaz Z, De Luca V, Tiwari AK, Squassina A, Zai GC, Shaikh SA, Strauss J, et al. Investigation of the genetic interaction between BDNF and DRD3 genes in suicidical behaviour in psychiatric disorders. World J Biol Psychiatry. 2015;16(3):171-9.

19. Croca MA, Mant R, Asherson P, Williams J, Hode Y, Mayerova A, Collier D, Lannfelt L, Sokoloff P, Schwartz JC, et al. Association between schizophrenia and homozygosity at the dopamine D3 receptor gene. J Med Genet. 1992; 29(12):858-60

20. Nimgaonkar VL, Sanders AR, Ganguli R, Zhang XR, Brar J, Hogge W, Fann WE, Patel PI, Chakravarti A. Association study of schizophrenia and the dopamine D3 receptor gene locus in two independent samples. Am J Med Genet. 1996;67(6):505-14

21. Feldcamp LA, Souza RP, Romano-Silva M, Kennedy JL, Wong AH. Reduced prefrontal cortex DARPP-32 mRNA in completed suicide victims with schizophrenia. Schizophr Res. 2008;103(1-3):192-200.

22. Chen CH, Liu MY, Wei FC, Koong FJ, Hwu HG, Hsiao KJ. Further evidence of no association between Ser9Gly polymorphism of dopamine D3 receptor gene and schizophrenia. Am J Med Genet. 1997;74(1):40-3.

23. Barlas IO, Cetin M, Erdal ME, Semiz UB, Basoglu C, Ay ME, Herken H, Uzun O. Lack of association between DRD3 gene polymorphism and response to clozapine in Turkish schizoprenia patients. Am J Med Genetics Part B Neuropsychiatric Genetics. 2009;150B(1):56-60.

24. Yao J, Pan YQ, Ding M, Pang H, Wang BJ. Association between DRD2 (rs1799732 and rs1801028) and ANKK1 (rs1800497) polymorphisms and schizophrenia: a meta-analysis. Am J Med Genetics Part B Neuropsychiatric Genetics. 2015;168B(1):1-13.

25. Lanara Z, Giannopoulou E, Fullen M, Kostantinopoulos E, Nebel JC, Kalofonos HP, Patrinos GP, Pavlidis C. Comparative study and meta-analysis of meta-analysis studies for the correlation of genomic markers with early cancer detection. Human Genomics. 2013;7:14.

26. Barendregt JJ, Doi SA, Lee YY, Norman RE, Vos T. Meta-analysis of prevalence. J Epidemiol Community Health. 2013;67(11):974-8.

27. Williams J, Spurlock G, Holmans P, Mant R, Murphy K, Jones L, Cardno A, Asherson P, Blackwood D, Muir W, et al. A meta-analysis and transmission disequilibrium study of association between the dopamine D3 receptor gene and schizophrenia. Mol Psychiatry. 1998;3(2):141-9.

28. Dubertret C, Gorwood P, Ades J, Feingold J, Schwartz JC, Sokoloff P. Metaanalysis of DRD3 gene and schizophrenia: ethnic heterogeneity and significant association in Caucasians. Am J Med Genet. 1998;81(4):318-22.

29. Jonsson EG, Flyckt L, Burgert E, Crocq MA, Forslund K, Mattila-Evenden M, Rylander G, Asberg M, Nimgaonkar VL, Edman G, et al. Dopamine D3 receptor gene Ser9Gly variant and schizophrenia: association study and meta-analysis. Psychiatr Genet. 2003;13(1):1-12.

30. Jonsson EG, Kaiser R, Brockmoller J, Nimgaonkar VL, Crocq MA. Metaanalysis of the dopamine D3 receptor gene (DRD3) Ser9Gly variant and schizophrenia. Psychiatr Genet. 2004;14(1):9-12.

31. Utsunomiya K, Shinkai T, De Luca V, Hwang R, Sakata S, Fukunaka Y, Chen HI, Ohmori O, Nakamura J. Genetic association between the dopamine D3 
gene polymorphism (Ser9Gly) and schizophrenia in Japanese populations: evidence from a case-control study and meta-analysis. Neurosci Lett. 2008; 444(2):161-5.

32. Nunokawa A, Watanabe $Y$, Kaneko N, Sugai T, Yazaki S, Arinami T, Ujike H, Inada $\mathrm{T}$, Iwata $\mathrm{N}$, Kunugi $\mathrm{H}$, et al. The dopamine D3 receptor (DRD3) gene and risk of schizophrenia: case-control studies and an updated metaanalysis. Schizophr Res. 2010;116(1):61-7.

33. Qi XL, Xuan JF, Xing JX, Wang BJ, Yao J. No association between dopamine D3 receptor gene Ser9Gly polymorphism (rs6280) and risk of schizophrenia: an updated meta-analysis. Neuropsychiatr Dis Treat. 2017;13:2855-65.

34. Yang Z, Thomas DC. Two-stage family-based designs for sequencing studies. BMC Proc. 2014;8(Suppl 1):S32.

35. Ewens WJ, Spielman RS: The TDT is a statistically valid test: comments on Wittkowski and Liu. Hum Hered 2004, 58(1):59-60; author reply 60-51; discussion 61-52.

36. Falk $C T$, Rubinstein P. Haplotype relative risks: an easy reliable way to construct a proper control sample for risk calculations. Ann Hum Genet. 1987:51(3):227-33.

37. Yang B, Chan RC, Jing J, Li T, Sham P, Chen RY. A meta-analysis of association studies between the 10-repeat allele of a VNTR polymorphism in the 3'-UTR of dopamine transporter gene and attention deficit hyperactivity disorder. Am J Med Genet B Neuropsychiatr Genet. 2007;144B(4):541-50.

38. Higgins JP, Thompson SG, Deeks JJ, Altman DG. Measuring inconsistency in meta-analyses. Bmj. 2003;327(7414):557-60.

39. Zintzaras $E$, loannidis JP. Heterogeneity testing in meta-analysis of genome searches. Genet Epidemiol. 2005;28(2):123-37.

40. Higgins JP, Thompson SG. Quantifying heterogeneity in a meta-analysis. Stat Med. 2002;21(11):1539-58.

41. Leonard T, Duffy JC. A Bayesian fixed effects analysis of the mantel-Haenszel model applied to meta-analysis. Stat Med. 2002;21(16):2295-312.

42. Macciardi F, Verga M, Kennedy JL, Petronis A, Bersani G, Pancheri $P$, Smeraldi E. An association study between schizophrenia and the dopamine receptor genes DRD3 and DRD4 using haplotype relative risk. Hum Hered. 1994:44(6):328-36.

43. Rothschild LG, Badner J, Cravchik A, Gershon ES, Gejman PV. No association detected between a D3 receptor gene-expressed variant and schizophrenia. Am J Med Genet. 1996;67(2):232-4.

44. Malhotra AK, Goldman D, Buchanan RW, Rooney W, Clifton A, Kosmidis MH, Breier A, Pickar D. The dopamine D3 receptor (DRD3) Ser9Gly polymorphism and schizophrenia: a haplotype relative risk study and association with clozapine response. Mol Psychiatry. 1998;3(1):72-5.

45. Kalsi G, Curtis D, Brynjolfsson J, Sigmundsson T, Petursson H, Butler R, Read T, Murphy P, Gurling HM. Tests of linkage, allelic and genotypic association between schizophrenia and the gene for the D3 dopamine receptor, DRD3. Psychiatr Genet. 1998;8(3):187-9.

46. Ambrosio AM, Kennedy JL, Macciardi F, Macedo A, Valente J, Dourado A, Oliveira CR, Pato C. Family association study between DRD2 and DRD3 gene polymorphisms and schizophrenia in a Portuguese population. Psychiatry Res. 2004;125(3):185-91.

47. Luxian Lu HZ, Guo S, Shi Y. Association between DRD3 gene Ser9Gly polymorphism and schizophrenia in center families. J Fourth Military Med Univ. 2005;26(24):2261-4

48. Yuhong Wang YS, Lu L, et al. Association of dopamine D3 receptor Ser9Gly polymorphism with schizophrenia. J Clin Psychol Med. 2006;16(1):38-9.

49. Talkowski ME, Mansour H, Chowdari KV, Wood J, Butler A, Varma PG, Prasad S, Semwal P, Bhatia T, Deshpande S, et al. Novel, replicated associations between dopamine D3 receptor gene polymorphisms and schizophrenia in two independent samples. Biol Psychiatry. 2006;60(6):570-7.

50. Pawel K, Hauser J, Skibinska M, Szczepankiewicz A, Dmitrzak-Weglarz M, Gorzkowska K, Pawlak J, Czerski PM. family based association study of DRD1, DRD2, DRD3, DRD4, DAT, COMT gene polymorphism in schizophrenia. Psychiatr Pol. 2010;44(3):405-13.

51. Prasad S, Deshpande SN, Bhatia T, Wood J, Nimgaonkar VL, Thelma BK. Association study of schizophrenia among Indian families. Am J Med Genet. 1999;88(4):298-300.

52. Kremer I, Rietschel M, Dobrusin M, Mujaheed M, Murad I, Blanaru M, Bannoura I, Muller DJ, Schulze TG, Reshef A, et al. No association between the dopamine D3 receptor Bal I polymorphism and schizophrenia in a family-based study of a Palestinian Arab population. Am J Med Genet. 2000; 96(6):778-80.
53. Zai CC, Manchia M, De Luca V, Tiwari AK, Squassina A, Zai GC, Strauss J, Shaikh SA, Freeman N, Meltzer HY, et al. Association study of BDNF and DRD3 genes in schizophrenia diagnosis using matched case-control and family based study designs. Prog Neuro Psychopharmacol Biol Psychiatry. 2010;34(8):1412-8

54. Ma G, He Z, Fang W, Tang W, Huang K, Li Z, He G, Xu Y, Feng G, Zheng T, et al. The Ser9Gly polymorphism of the dopamine D3 receptor gene and risk of schizophrenia: an association study and a large meta-analysis. Schizophr Res. 2008;101(1-3):26-35.

55. Haldar T, Ghosh S. Statistical equivalent of the classical TDT for quantitative traits and multivariate phenotypes. J Genet. 2015;94(4):619-28.

56. Leung PW, Chan JK, Chen LH, Lee CC, Hung SF, Ho TP, Tang CP, Moyzis RK, Swanson JM. Family-based association study of DRD4 gene in methylphenidate-responded attention deficit/hyperactivity disorder. PLoS One. 2017;12(3):e0173748.

\section{Publisher's Note}

Springer Nature remains neutral with regard to jurisdictional claims in published maps and institutional affiliations.

Ready to submit your research? Choose BMC and benefit from:

- fast, convenient online submission

- thorough peer review by experienced researchers in your field

- rapid publication on acceptance

- support for research data, including large and complex data types

- gold Open Access which fosters wider collaboration and increased citations

- maximum visibility for your research: over $100 \mathrm{M}$ website views per year

At BMC, research is always in progress.

Learn more biomedcentral.com/submissions 